\title{
Serosurvey for tick-borne diseases in dogs from the Eastern Amazon, Brazil
}

\author{
Pesquisa Sorológica por doenças transmitidas por carrapatos em cães da Amazônia oriental, Brasil \\ Mariana Granziera Spolidorio ${ }^{1}$; Antonio Humberto Hamad Minervino ${ }^{1,2}$; Samantha Yuri Oshiro Branco Valadas ${ }^{1}$; \\ Herbert Sousa Soares ${ }^{1}$; Kedson Alessandri Lobo Neves ${ }^{2}$; Marcelo Bahia Labruna ${ }^{1}$; \\ Múcio Flavio Barbosa Ribeiro ${ }^{3}$; Solange Maria Gennari ${ }^{1 *}$ \\ ${ }^{1}$ Departamento de Medicina Veterinária Preventiva e Saúde Animal, Faculdade de Medicina Veterinária e Zootecnia, \\ Universidade de São Paulo - USP, São Paulo, SP, Brazil \\ ${ }^{2}$ Instituto de Biodiversidade e Floresta, Universidade Federal do Oeste do Pará - UFOPA, Santarém, PA, Brazil \\ ${ }^{3}$ Departamento de Parasitologia - ICB, Universidade Federal de Minas Gerais - UFMG, Belo Horizonte, MG, Brazil
}

Received June 18, 2012

Accepted February 1, 2013

\begin{abstract}
Canine ehrlichiosis and babesiosis are the most prevalent tick-borne diseases in Brazilian dogs. Few studies have focused attention in surveying tick-borne diseases in the Brazilian Amazon region. A total of 129 blood samples were collected from dogs living in the Brazilian eastern Amazon. Seventy-two samples from dogs from rural areas of 19 municipalities and 57 samples from urban stray dogs from Santarém municipality were collected. Serum samples were submitted to Indirect Immunofluorescence Assay (IFA) with antigens of Babesia canis vogeli, Ehrlichia canis, and six Rickettsia species. The frequency of dogs containing anti-B. canis vogeli, anti-E. canis, and anti-Rickettsia spp. antibodies was $42.6 \%, 16.2 \%$, and $31.7 \%$, respectively. Anti-B. canis vogeli antibodies were detected in $59.6 \%$ of the urban dogs, and in $29.1 \%$ of the rural dogs $(P<0.05)$. For E. canis, seroprevalence was similar among urban $(15.7 \%)$ and rural $(16.6 \%)$ dogs. For Rickettsia spp., rural dogs presented significantly higher $(P<0.05)$ prevalence $(40.3 \%)$ than urban animals $(21.1 \%)$. This first study on tick-borne pathogens in dogs from the Brazilian eastern Amazon indicates that dogs are exposed to several agents, such as Babesia organisms, mostly in the urban area; Spotted Fever group Rickettsia organisms, mostly in the rural area; and Ehrlichia organisms, in dogs from both areas studied.
\end{abstract}

Keywords: Ehrlichia, Babesia, Rickettsia, dogs, Amazon, Pará state.

\section{Resumo}

Ehrliquiose canina e babesiose canina são as doenças parasitárias transmitidas por carrapatos de maior prevalência em cáes do Brasil. Poucos estudos pesquisaram doenças transmitidas por carrapatos na região da Amazônia brasileira. Um total de 129 amostras de sangue foram colhidas de cães da Amazônia oriental brasileira. Setenta e dois cães eram de áreas rurais de 19 municípios do Estado do Pará, e 57 amostras foram colhidas de cães errantes vadios da área urbana do município de Santarém-PA. As amostras de soro foram submetidas ao ensaio de imunofluorescência indireta, com antígenos de Babesia canis vogeli, Ehrlichia canis, e seis espécies de Rickettsia. A frequência de cães com anticorpos anti-B. canis vogeli, anti-E. canis, e anti-Rickettsia spp. foi de $42,6 \%, 16,2 \%$ e $31,7 \%$, respectivamente. Anticorpos anti- $B$. canis vogeli foram detectados em $59,6 \%$ dos cáes urbanos, e em $29,1 \%$ dos cães rurais $(P<0.05)$. Para E. canis, a soroprevalência foi parecida entre os cáes urbanos $(15,7 \%)$ e rurais $(16,6 \%)$. Para Rickettsia spp., cães rurais apresentaram prevalência $(P<0.05)$ significativamente maior $(40,3 \%)$ do que os cáes urbanos $(21,1 \%)$. Esse primeiro estudo sobre agentes transmitidos por carrapatos entre cães da Amazônia oriental brasileira indica que estes animais estão expostos a vários agentes. Estes incluem Babesia principalmente na área urbana, Riquétsias do grupo da Febre Maculosa principalmente nas áreas rurais, e Erliquia em cáes de ambas as áreas, rural e urbana.

Palavras-chave: Ehrlichia, Babesia, Rickettsia, cães, Amazônia, Pará.

\footnotetext{
${ }^{*}$ Corresponding author: Solange Maria Gennari

Departamento de Medicina Veterinária Preventiva e Saúde Animal, Facul-

dade de Medicina Veterinária e Zootecnia, Universidade de São Paulo - USP,

Av. Orlando Marques de Paiva, 87, Cidade Universitária, CEP 05508-270,

São Paulo, SP, Brazil

e-mail: sgennari@usp.br
} 


\section{Introduction}

Tick-borne diseases have been increasingly studied in Brazil, but there are still many unexplored places, especially in the Amazon region. Canine babesiosis is a tick-borne disease of domestic and wild canids characterized by fever, depression, and anaemia (KUTTLER, 1988). Previous parasitological and serological studies carried out in Brazil have shown that canine babesiosis due to Babesia canis is distributed among different states with rates of seropositivity ranging from 1.9 to $66.9 \%$ in Minas Gerais (RIBEIRO et al., 1990; RODRIGUES et al., 2002; BASTOS et al., 2004; SOARES et al., 2006), 35.7\% in Paraná (TRAPP et al., 2006), 5.2\% in Rio de Janeiro (O'DWYER et al., 2001), and $10.3 \%$ in São Paulo (DELL'PORTO et al., 1993). In addition, the disease was also reported in the state of Mato Grosso, where it was molecularly confirmed as $B$. canis vogeli (SPOLIDORIO et al., 2011).

Canine monocytic ehrlichiosis, caused by Ehrlichia canis, is the most important tick-borne disease of dogs in Brazil. Currently, Ehrlichia canis is the only Ehrlichia species that has been isolated in cell culture from vertebrates in South America. A preliminary investigation for Ehrlichia species in the northern and southeastern regions of Brazil failed to detect Ehrlichia DNA in Amblyomma ticks, humans, dogs, capybaras, and febrile human blood samples (LABRUNA et al., 2007a). In contrast, ehrlichial DNA compatible with Ehrlichia chaffeensis, Ebrlichia ewingii, or an agent closely related to Ehrlichia ruminantium were recently reported in animal blood samples from southeastern Brazil (MACHADO et al., 2006; OLIVEIRA et al., 2009; WIDMER et al., 2011).

Most of the published studies on tick-borne diseases in the Brazilian Amazon region have focused on rickettsiosis, mainly in western Amazon, state of Rondônia (LABRUNA et al., 2004, 2007b). In the aforementioned region, some Rickettsia species were described for the first time in Brazil. At the same time, there is no information on rickettsioses from the eastern part of the Amazon.

In this study, we evaluated seroprevalence to Babesia canis vogeli, Ehrlichia canis, and Rickettsia spp. in dogs from rural and urban areas within the state of Pará, eastern Amazon, Brazil.

\section{Materials and Methods}

During 2008-2009, a total of 129 dogs of different breeds and ages were sampled from an urban area and from different farms in rural areas. Those samples were also used for a serological study to investigate the prevalence of Neospora caninum, Toxoplasma gondii, and Leishmania infantum (formerly chagasi), as previously described (VALADAS et al., 2010). Of all the dogs, $77(59.7 \%)$ were males and $52(40.3 \%)$ were females; 57 samples $(44.2 \%)$ were collected from urban stray dogs from the municipality of Santarém, and $72(55.8 \%)$ were from dogs from 39 rural properties in 20 different municipalities. Figure 1 shows the municipalities where the respective numbers of dogs were sampled. The rural properties were selected from a prevalence study of other parasitic and infection agents in cattle (MINERVINO et al., 2008; CHIEBAO, 2010). Blood samples were collected from the jugular or brachial vein of the dogs, and sera was obtained by centrifugation. Samples were stored at $-20^{\circ} \mathrm{C}$ until tested.

Serum samples were submitted to indirect immunofluorescence assay (IFA) with antigens of $B$. canis vogeli (blood smears from splenectomized dogs that were experimentally infected in our lab) according to Bicalho et al. (2004), using a screening dilution of 1:64. To detect antibodies against $E$. canis, the bacteria were cultivated in DH82 cells, as described by Aguiar et al. (2007a), and serum samples were analyzed following the protocol by Silva et al. (2010), but with a screening dilution of 1:80. For Rickettsia spp., IFA was run using the screening dilution of 1:64 against six Rickettsia species that occur in Brazil, namely $R$. rickettsii, $R$. parkeri, R. amblyommii, R. rhipicephali, R. bellii, and $R$. felis, which were cultivated in Vero or C6/36 cells (LABRUNA et al., 2007b; HORTA et al., 2004). Samples with IFA reaction at the cut-off point for each agent were considered positive and further tested in two-fold serial dilution to determine endpoint titers. Serum of a Rickettsia species showing titer at least 4-fold higher than those observed for the other Rickettsia species was considered homologous to the first Rickettsia species or to a very closely related species (HORTA et al., 2004, 2010; LABRUNA et al., 2007b; PIRANDA et al., 2008; SAITO et al., 2008).

Possible statistical associations between gender or location (rural or urban) of dogs and the occurrence of anti- B. canis vogeli, E. canis, or any of the six Rickettsia species antibodies were analyzed by Pearson's chi-square test using Minitab statistical software (Minitab 2000). The significance adopted was 5\%.

\section{Results}

The distance between the visited farms varied from 10 to $1,000 \mathrm{~km}$. From the 20 municipalities visited, only three (Canaã dos Carajás, Ourilândia do Norte, and São João do Araguaia) presented negative results to all tested samples. From the 129 samples tested for B. canis vogeli, 55 (42.6\%) were positive, being 34 (59.6\%) from urban dogs and 21 (29.1\%) from rural dogs. Antibodies against $B$. canis vogeli were detected in dogs from 10 different municipalities (Conceição do Araguaia, Itupiranga, Jacundá, Marabá, Redenção, Santa Maria das Barreiras, Santana do Araguaia, Santarém, São Felix do Xingu, and Tucumã).

From the tested samples (129), $21(16.2 \%)$ were positive to E. canis, being 9 (15.7\%) from urban dogs and 12 (16.6\%) from rural dogs from eight different municipalities (Água Azul do Norte, Altamira, Belterra, Conceição do Araguaia, Jacundá, Pau D'Arco, Redençáo, and Santana do Araguaia). The highest anti-E. canis endpoint titer found in dogs from either rural or urban areas was 81,720 .

Sera from 41 (31.7\%) out of 129 canine samples were positive to at least one Rickettsia species, being 29 (24.8\%) rural dogs from 13 different municipalities (Conceição do Araguaia, Itupiranga, Jacundá, Marabá, Novo Repartimento, Pau D’Arco, Redenção, Santa Maria das Barreiras, Santana do Araguaia, Santarém, São Felix do Xingu, São Domingos do Araguaia, and Tucumã) and $12(21 \%)$ urban stray dogs from Santarém municipality. From the six Rickettsia species tested, only four were considered to be possibly present at the studied regions $(R$. bellii in at least eight 


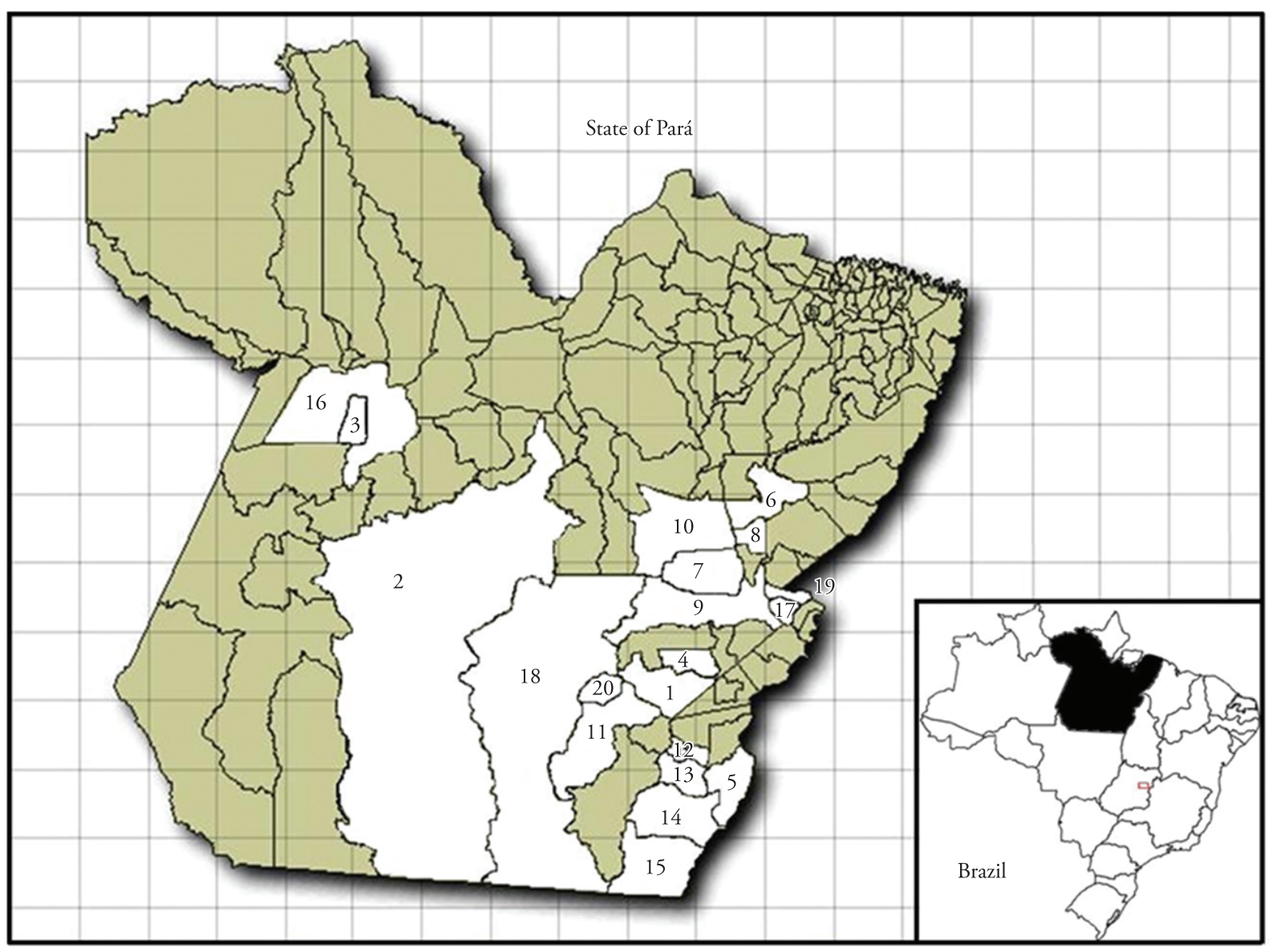

Figure 1. Map of Pará state with the municipalities where canine serum samples were collected (number of dogs). 1 Água Azul do Norte (one); 2 Altamira (six); 3 Belterra (one); 4 Canaã dos Carajás (one); 5 Conceição do Araguaia (11); 6 Goianésia do Pará (two); 7 Itupiranga (six); 8 Jacundá (eight); 9 Marabá (four); 10 Novo Repartimento (two); 11 Ourilândia do Norte (two); 12 Pau D’Arco (two); 13 Redenção (four); 14 Santa Maria das Barreiras (two); 15 Santana do Araguaia (six); 16 Santarém (three rural, 57 urban); 17 São Domingos do Araguaia (two); 18 São Felix do Xingu (two); 19 São João do Araguaia (1); 20 Tucumá (six).

dogs, $R$. rhipicephali in two dogs, $R$. rickettsii in one dog, and $R$. amblyommii in eight dogs). Canine endpoint titers to Rickettsia spp. antigens are presented in Table 1 . A total of 30, 20, 15, 12, 11 , and nine dogs were reactive to $R$. amblyommii, $R$. rhipicephali, $R$. parkeri, $R$. bellii, $R$. rickettsii, and $R$. felis, respectively. Endpoint titers varied from 64 to 8,192 for $R$. amblyommii. At least half of the $30 R$. amblyommii-seroreactive dogs had endpoint titers $\geq 1024$ for $R$. amblyommii. Endpoint titers for the other Rickettsia species ranged as follows: $R$. rhipicephali, 64-8,192; $R$. bellii, 128-8,192; $R$. parkeri, 128-2,148; $R$. rickettsii, 64-2,148; and $R$. felis, 64-512. While the median of the individual titers against both $R$. amblyommii and $R$. rhipicephali was 1,024, the median for the titers against $R$. bellii, $R$. parkeri, $R$. rickettsii, and $R$. felis were 512, 256, 128, and 256, respectively.

Regarding $B$. canis vogeli, female dogs presented significantly higher prevalence $(53.8 \%)$ than male dogs $(35.1 \%)(P=0.046)$. In addition, $B$. canis vogeli seropositivity was significantly higher $(P<0.01)$ among urban $(59.7 \%)$ than rural $(29.2 \%)$ dogs. For E. canis, there was no association between the frequency of positive animals and the independent variables evaluated $(P>0.05)$. For Rickettsia spp., no association $(P>0.05)$ was found relating to gender, but rural dogs presented significantly higher prevalence (40.3\%) than urban animals $(21.1 \%)(P=0.02)$.

Antibodies for the three genera of tick-borne pathogens were not found simultaneously in any of the dogs. Antibodies for at least two genera were found in $16(22.2 \%)$ dogs from the rural area, with highest association between E. canis and Rickettsia spp. (56.2\%). In the urban area, there were 17 (29.8\%) animals with positive results to at least two genera, where $E$. canis and Rickettsia spp. (58.8\%) were again the most prevalent. However, no statistically significant correlation was found in positivity for the different pathogens.

\section{Discussion and Conclusions}

To the best of our knowledge, Babesia species in dogs from the Amazon region has never been reported. Due to this lack of information about canine babesiosis in the Brazilian Amazon region, the occurrence of positive dogs to $B$. canis vogeli (42.6\%) can only be compared to other Brazilian studies, in which the prevalence of antibodies against this parasite in sera from dogs varied from $35.7 \%$ in Paraná state (TRAPP et al., 2006) to 66.9\% in Minas 
Gerais state (RIBEIRO et al., 1990). We can infer from our results that the higher seroprevalence to $B$. canis vogeli observed among urban dogs is probably due to the predominating tick species recently found in the urban area of the municipality of Santarém, namely, $R$. sanguineus (SERRA-FREIRE, 2010), which is the only known vector of $B$. canis vogeli (DANTAS-TORRES, 2008).
Ehrlichia was first reported in Brazil in 1973, in dogs from Minas Gerais state, southeastern Brazil (COSTA et al., 1973). From the 26 Brazilian states, only one remains with no report on Ehrlichia species, as recently reviewed or reported (SPOLIDORIO et al., 2010; AZEVEDO et al., 2011; VIEIRA et al., 2011). Considering the Legal Amazon region, the only reports on Ehrlichia species are

Table 1. Endpoint titers from the positive sera tested by indirect immunofluorescence assay (IFA) for six Rickettsia species in dogs from the urban and rural areas of the state of Pará, Brazilian Amazon.

\begin{tabular}{|c|c|c|c|c|c|c|c|}
\hline \multicolumn{8}{|c|}{ IFA titers for Rickettsia antigens } \\
\hline Dog area/sera & R. rickettsii & R. parkeri & R. amblyommii & R. rhipicephali & R. felis & R. bellii & PAIHR \\
\hline \multicolumn{8}{|l|}{ Urban } \\
\hline 10 & NR & NR & NR & NR & NR & 8192 & R. bellii \\
\hline 14 & 64 & 128 & 256 & 1024 & NR & NR & R. rhipicephali \\
\hline 15 & 256 & 128 & 64 & NR & NR & NR & \\
\hline 17 & NR & NR & $\mathrm{NR}$ & NR & $\mathrm{NR}$ & 128 & R. bellii \\
\hline 19 & 256 & 128 & NR & NR & NR & NR & \\
\hline 20 & NR & 256 & 128 & NR & NR & NR & \\
\hline 25 & 64 & NR & NR & NR & NR & NR & \\
\hline 28 & NR & NR & NR & NR & NR & 1024 & R. bellii \\
\hline 43 & 256 & NR & NR & NR & NR & NR & R. rickettsii \\
\hline 52 & NR & NR & NR & NR & NR & 2048 & R. bellii \\
\hline 54 & NR & NR & NR & NR & NR & 1024 & R. bellii \\
\hline 57 & NR & NR & NR & NR & NR & 2048 & R. bellii \\
\hline \multicolumn{8}{|l|}{ Rural } \\
\hline 1 & NR & NR & 1024 & NR & NR & NR & R. amblyommii \\
\hline 3 & NR & 256 & 4096 & 1024 & NR & NR & R. amblyommii \\
\hline 10 & 128 & 256 & 8192 & 1024 & 256 & NR & R. amblyommii \\
\hline 14 & NR & NR & 256 & NR & NR & NR & R. amblyommii \\
\hline 15 & NR & NR & 64 & NR & NR & NR & \\
\hline 18 & NR & NR & 64 & NR & NR & NR & \\
\hline 20 & NR & NR & 1024 & 64 & 64 & NR & R. amblyommii \\
\hline 21 & NR & NR & 128 & NR & NR & NR & R. amblyommii \\
\hline 22 & NR & NR & 64 & 64 & NR & NR & \\
\hline 24 & NR & 256 & 2048 & 1024 & NR & NR & \\
\hline 28 & NR & NR & NR & NR & NR & 512 & R. bellii \\
\hline 37 & NR & 256 & 2048 & 1024 & NR & 256 & \\
\hline 38 & 2048 & 2048 & 8192 & 8192 & 256 & 128 & \\
\hline 43 & NR & NR & 256 & NR & NR & 256 & \\
\hline 44 & NR & NR & NR & NR & NR & 512 & R. bellii \\
\hline 46 & NR & NR & 512 & 256 & NR & NR & \\
\hline 48 & NR & NR & 128 & NR & NR & NR & R. amblyommii \\
\hline 51 & NR & NR & 64 & 256 & NR & NR & R. rhipicephali \\
\hline 52 & 128 & 512 & 4096 & 2048 & 512 & NR & \\
\hline 53 & NR & NR & 256 & 128 & NR & NR & \\
\hline 54 & NR & NR & 1024 & 1024 & NR & NR & \\
\hline 55 & NR & NR & 1024 & 512 & 128 & NR & \\
\hline 56 & NR & NR & 512 & 256 & 64 & NR & \\
\hline 57 & NR & 512 & 4096 & 2048 & 128 & 256 & \\
\hline 60 & NR & 512 & 1024 & 128 & 256 & NR & \\
\hline 62 & NR & 128 & 1024 & NR & NR & NR & R. amblyommii \\
\hline 63 & 128 & 128 & 2048 & 1024 & NR & NR & \\
\hline 66 & 64 & NR & NR & NR & NR & NR & \\
\hline 68 & NR & NR & 512 & 256 & NR & NR & \\
\hline 69 & 256 & 1024 & 2048 & 2048 & 512 & NR & \\
\hline
\end{tabular}

PAIHR: possible antigen involved in a homologous reaction (a homologous reaction was determined when an endpoint titer to a Rickettsia species was at least 4-fold higher than those observed for the other Rickettsia species). NR: non-reagent at 1:64 serum dilution 
from Rondônia state (western Amazon), where 36\% of dogs were seroreactive to E canis by IFA (AGUIAR et al., 2007b; VIEIRA et al., 2011). Also in Rondônia state, Labruna et al. (2007a) found four out of five dogs infected with $E$. canis by molecular methods, which was the first molecular report of E. canis in the Amazon region. We have sampled a total of 129 domestic dogs from 20 different municipalities in the state of Pará and found 21 (16.2\%) positive results to E. canis by IFA. Our results showed lower occurrence when compared to previous studies in dogs from western Amazon.

Overall, serum endpoint titers to Rickettsia spp. indicate that seropositive rural dogs had been predominately infected by $R$. amblyommii or by a closely related genotype, whereas seropositive urban dogs had been predominately infected by $R$. bellii or closely related genotypes (Table 1). Even though we have not recorded ectoparasitism of dogs, it has been reported that $R$. amblyommii infects exclusively ticks of the genus Amblyomma. In fact, in the Brazilian Amazonian region, $R$. amblyommii was detected in Amblyomma cajennense, Amblyomma coelebs, Amblyomma longirostre, and Amblyomma geayi (LABRUNA et al. 2004, 2011). The former two ticks are known to parasitize dogs within the rural areas of the Amazon region (LABRUNA et al., 2005). Therefore, they might be related to the serological status of the dogs of the present study. Urban dogs reacted predominately to the nonSpotted Fever group agent $R$. bellii, an observation that should be further evaluated. It is worth mentioning that this rickettsia and closely related genotypes have been reported infecting species of nearly all tick genera of the New World (PHILIP et al., 1983, LABRUNA et al., 2011), as well as a broad range of insects and diverse organisms, including amoeba (WEINERT et al., 2009).

In contrast to southern and southeastern Brazil, rickettsioses have never been reported in humans from northern Brazil (the Amazon region) (Labruna et al., 2011). Indeed, our results indicate that there is circulation of a Spotted Fever group agent closely related to $R$. amblyommii in the rural area of the study region. To date, $R$. amblyommii is still considered of unknown pathogenicity. However, it has been proposed that some of the rickettsiosis cases reported as Rocky Mountain spotted fever (RMSF) (presumably caused by $R$. rickettsii) in the USA may have been caused by $R$. amblyommii (APPERSON et al., 2008). This assumption relied on serological results, which demonstrated a four-fold increase in endpoint titers to $R$. amblyommii, but not to $R$. rickettsii, in acute and convalescent sera samples taken from clinical cases compatible with RMSF (APPERSON et al., 2008).

In summary, this first study on tick-borne agents in dogs from the Brazilian eastern Amazon indicates that these dogs are exposed to several vector-borne infectious agents. These include Babesia organisms, mostly in the urban area, where $B$. canis vogeli is possibly being transmitted by $R$. sanguineus ticks; and Spotted Fever group Rickettsia organisms, mostly in the rural area, where $R$. amblyommii is possibly being transmitted by Amblyomma ticks. In addition, dogs from both rural and urban areas are similarly exposed to Ehrlichia organisms. While it is well known that E. canis is transmitted by $R$. sanguineus ticks in the urban areas of the Amazon region, it is possible that other Ehrlichia species are transmitted by native tick species in the rural areas, resulting in similar seroprevalence values between urban and rural dogs. Further studies on tick species and isolation of tick-borne agents from ticks and vertebrate hosts in the Amazon region are needed to better elucidate the epidemiology of tick-borne diseases in the region.

\section{Acknowledgments}

The authors are grateful to the 'Fundação de Amparo à Pesquisa do Estado de São Paulo' (FAPESP) for the grants to MGS and HSS and to 'Conselho Nacional de Desenvolvimento Científico e Tecnológico' (CNPq) for the grants to SYOBV, MBL, MFBR, AHHM and SMG.

\section{Conflict of interest statement}

The authors declare that they have no competing interests.

\section{References}

Aguiar DM, Saito TB, Hagiwara MK, Machado RZ, Labruna MB. Diagnóstico sorológico de erliquiose canina com antígeno brasileiro de Ehrlichia canis. Cienc Rural 2007a; 37(3): 796-802. http://dx.doi. org/10.1590/S0103-84782007000300030

Aguiar DM, Cavalcante GT, Pinter A, Gennari SM, Camargo LM, Labruna MB. Prevalence of Ehrlichia canis (Rickettsiales: Anaplasmataceae) in dogs and Rhipicephalus sanguineus (Acari: Ixodidae) ticks from Brazil. J Med Entomol 2007b; 44(1): 126-132. http://dx.doi. org/10.1603/0022-2585(2007)44[126:POECRA]2.0.CO;2

Apperson CS, Engber B, Nicholson WL, Mead DG, Engel J, Yabsley MJ, et al. Tick-borne diseases in North Carolina: Is "Rickettsia amblyommii" a possible cause of rickettsiosis reported as Rocky Mountain spotted fever? Vector Borne Zoonotic Dis 2008; 8(5): 597-606. PMid:18447622. http://dx.doi.org/10.1089/vbz.2007.0271

Azevedo SS, Aguiar DM, Aquino SF, Orlandelli RC; Fernandes ARF, Uchôa ICP. Soroprevalência e fatores de risco associados à soropositividade para Ehrlichia canis em cáes do semiárido da Paraíba. BrazJ Vet Res Anim Sci 2011; 48(1): 14-18.

Bastos CV, Moreira SM, Passos LM. Retrospective study (1998-2001) on canine babesiosis in Belo Horizonte, Minas Gerais, Brazil. Ann NY Acad Sci 2004; 1026: 158-160. PMid:15604486. http://dx.doi.org/10.1196/ annals.1307.023

Bicalho KA, Ribeiro MF, Martins-Filho OA. Molecular fluorescent approach to assessing intraerythrocytic hemaprotozoan Babesia canis infection in dogs. Vet Parasitol 2004; 125(3-4): 221-235. PMid:15482880. http://dx.doi.org/10.1016/j.vetpar.2004.08.009

Chiebao DP. Frequência de anticorpos anti-Neospora caninum, antiBrucella abortus e anti-Lesptospira spp. em bovinos do Estado do Pará: estudo de possíveis variáveis para ocorrência de infecção [Dissertação]. São Paulo: Universidade de São Paulo; 2010.

Costa JO, Batista Júnior JA, Silva M, Guimarães PM. Ehrlichia canis infection in dog in Belo Horizonte - Brazil. Arq Esc Vet UFMG 1973; 25(2): 199-206.

Dantas-Torres F. Causative agents of canine babesiosis in Brazil. Prev Vet Med 2008; 83(2): 210-211. PMid:17980446. http://dx.doi. org/10.1016/j.prevetmed.2007.03.008

Dell'Porto A, Oliveira MR, Miguel O. Babesia canis in stray dogs from the city of São Paulo Comparative studies between the clinical and hematological aspects and the indirect fluorescence antibody test. Rev Bras Parasitol Vet 1993; 2(1): 37-40. 
Horta MC, Labruna MB, Sangioni LA, Vianna MCB, Gennari SM, Galvão MAM, et al. Prevalence of antibodies to Spotted Fever Group Rickettsiae in humans and domestic animals in a Brazilian Spotted FeverEndemic area in the State of São Paulo, Brazil: Serologic evidence for infection by Rickettsia rickettsii and another spotted fever group Rickettsia. Am J Trop Med Hyg 2004; 71(1): 93-97. PMid:15238696.

Horta MC, Sabatini GS, Moraes-Filho J, Ogrzewalska M, Canal RB, Pacheco RC, et al. Experimental Infection of the Opossum Didelphis aurita by Rickettsia felis, Rickettsia bellii and Rickettsia parkeri and Evaluation of the Transmission of the Infection to Ticks Amblyomma cajennense and Amblyomma dubitatum. Vector Borne Zoonotic Dis 2010; 10(10): 959-967. PMid:20455783. http://dx.doi.org/10.1089/ vbz.2009.0149

Kuttler KL. Worldwide impact of babesiosis. In: Ristic M. Babesiosis of Domestic Animals and Man. Boca Raton: CRC Press; 1988. 1-22.

Labruna MB, Whitworth T, Bouyer DH, McBride J, Camargo LM, Camargo EP, et al. Rickettsia bellii and Rickettsia amblyommii in Amblyomma ticks from the State of Rondônia, Western Amazon, Brazil. JMed Entomol 2004; 41(6): 1073-1081. PMid:15605647. http://dx.doi. org/10.1603/0022-2585-41.6.1073

Labruna MB, Camargo LM, Camargo EP, Walker DH. Detection of a spotted fever group Rickettsia in the tick Haemaphysalis juxtakochi in Rondonia, Brazil. Vet Parasitol 2005; 127(2): 169-174. PMid:15631911. http://dx.doi.org/10.1016/j.vetpar.2004.09.024

Labruna MB, McBride JW, Camargo LM, Aguiar DM, Yabsley MJ, Davidson WR, et al. A preliminary investigation of Ehrlichia species in ticks, humans, dogs, and capybaras from Brazil. Vet Parasitol 2007a; 143(2): 189-195. PMid:16962245. http://dx.doi. org/10.1016/j.vetpar.2006.08.005

Labruna MB, Horta MC, Aguiar DM, Cavalcante GT, Pinter A, Gennari SM, et al. Prevalence of Rickettsia infection in dogs from the urban and rural areas of Monte Negro municipality, western Amazon, Brazil. Vector Borne Zoonotic Dis 2007b; 7(2): 249-255. PMid:17627445. http:// dx.doi.org/10.1089/vbz.2006.0621

Labruna MB, Mattar S, Nava S, Bermudez S, Venzal JM, Dolz G, et al. Rickettsioses in Latin America, Caribbean, Spain and Portugal. Rev MVZ Córdoba 2011; 16(2): 2435-2457.

Machado RZ, Duarte JM, Dagnone AS, Szabó MP. Detection of Ehrlichia chaffeensis in Brazilian marsh deer (Blastocerus dichotomus). Vet Parasitol 2006; 139(1-3): 262-266. PMid:16621285. http://dx.doi. org/10.1016/j.vetpar.2006.02.038

Minervino AH, Ragozo AM, Monteiro RM, Ortolani EL, Gennari SM. Prevalence of Neospora caninum antibodies in cattle from Santarém, Pará, Brazil. Res Vet Sci 2008; 84(2): 254-256. PMid:17619028. http://dx.doi. org/10.1016/j.rvsc.2007.05.003

O’Dwyer LH, Massard CL, Pereira de Souza JCP. Hepatozoon canis infection associated with dog ticks of rural areas of Rio de Janeiro State, Brazil. Vet Parasitol 2001; 94(3): 143-150. http://dx.doi.org/10.1016/ S0304-4017(00)00378-2

Oliveira LS, Oliveira KA, Mourão LC, Pescatore AM, Almeida MR, Conceição LG, et al. First report of Ehrlichia ewingii detected by molecular investigation in dogs from Brazil. Clin Microbiol Infect 2009; 15(S2): 55-56. PMid:19416280. http://dx.doi.org/10.1111/ j.1469-0691.2008.02635.x

Philip RN, Casper EA, Anacker RL, Cory J, Hayes SF, Burgdorfer W, et al. Rickettsia belli sp. nov.: a tick-borne rickettsia, widely distributed in the USA, that is distinct from the spotted fever and typhus biogroups. Int J Syst Bacteriol 1983; 33(1): 94-106. http://dx.doi. org/10.1099/00207713-33-1-94
Piranda EM, Faccini JL, Pinter A, Saito TB, Pacheco RC, Hagiwara $\mathrm{MK}$, et al. Experimental infection of dogs with a Brazilian strain of Rickettsia rickettsii: clinical and laboratory findings. Mem Inst Oswaldo Cruz 2008; 103(7): 696-701. PMid:19057821. http://dx.doi. org/10.1590/S0074-02762008000700012

Ribeiro MFB, Passos LMF, Lima JD, Guimarães AM. Frequency of anti-Babesia canis antibodies in dogs, in Belo Horizonte, Minas Gerais. Arq Bras Med Vet Zootec 1990; 42(6):511-517.

Rodrigues AFSF, D’Agosto M, Daemon E. Babesia canis (Piana \& GalliValerio, 1895) (Apicomplexa: Babesiidae) em cães de rua do Município de Juiz de Fora, MG. Rev Bras Med Vet 2002; 24(1): 17-21.

Saito TB, Cunha-Filho NA, Pacheco RC, Ferreira F, Pappen FG, Farias NA, et al. Canine infection by rickettsiae and ehrlichiae in southern Brazil. Am J Trop Med Hyg 2008; 79(1): 102-108. PMid:18606772.

Serra-Freire NM. Occurrence of ticks (Acari: Ixodidae) on human hosts, in three municipalities in the State of Pará, Brazil. Rev Bras Parasitol Vet 2010; 19(3): 141-147. PMid:20943016. http://dx.doi.org/10.1590/ S1984-29612010000300003

Silva JN, Almeida ABPF, Boa Sorte EC, Freitas AG, Santos LGF, Aguiar DM, et al. Seroprevalence anti-Ehrlichia canis antibodies in dogs of Cuiabá, Mato Grosso. Rev Bras Parasitol Vet 2010; 19(2): 108-111. PMid:20624348. http://dx.doi.org/10.4322/rbpv.01902008

Soares AO, Souza AD, Feliciano EA, Rodrigues AF, D’Agosto M, Daemon E. Avaliação ectoparasitológica e hemoparasitológica em cães criados em apartamentos e casas com quintal na cidade de Juiz de Fora, MG. Rev Bras Parasitol Vet 2006; 15(1): 13-16. PMid:16646996.

Spolidorio MG, Labruna MB, Machado RZ, Moraes-Filho J, Zago AM, Donatele DM, et al. Survey for tick-borne zoonoses in the state of Espírito Santo, southeastern Brazil. Am J Trop Med Hyg 2010; 83(1): 201206. PMid:20595502 PMCid:2912600. http://dx.doi.org/10.4269/ ajtmh.2010.09-0595

Spolidorio MG, Torres MM, Campos WNS, Melo ALT, Igarashi M, Amude AM, et al. Molecular detection of Hepatozoon canis and Babesia canis vogeli in domestic dogs from Cuiabá, Brazil. Rev Bras Parasitol Vet 2011; 20(3): 253-255. PMid:21961759. http://dx.doi.org/10.1590/ S1984-29612011000300015

Trapp SM, Dagnone AS, Vidotto O, Freire RL, Amude AM, Morais HS. Seroepidemiology of canine babesiosis and ehrlichiosis in a hospital population. Vet Parasitol 2006; 140(3-4): 223-230. PMid:16647817. http://dx.doi.org/10.1016/j.vetpar.2006.03.030

Valadas S, Minervino AHH, Lima VMF, Soares RM, Ortolani EL, Gennari SM. Occurrence of antibodies anti-Neospora caninum, antiToxoplasma gondii, and anti-Leishmania chagasi in serum of dogs from Pará State, Amazon, Brazil. Parasitol Res 2010; 107(2): 453-457. PMid:20445991. http://dx.doi.org/10.1007/s00436-010-1890-2

Vieira RF, Biondo AW, Guimarães AM, Dos Santos AP, Dos Santos RP, Dutra LH, et al. Ehrlichiosis in Brazil. Rev Bras Parasitol Vet 2011; 20(1): 1-12. PMid:21439224. http://dx.doi.org/10.1590/ S1984-29612011000100002

Weinert LA, Werren JH, Aebi A, Stone GN, Jiggins FM. Evolution and diversity of Rickettsia bacteria. BMC Biol 2009; 7: 6. PMid:19187530 PMCid:2662801. http://dx.doi.org/10.1186/1741-7007-7-6

Widmer CE, Azevedo FC, Almeida AP, Ferreira F, Labruna MB. Tickborne bacteria in free living jaguars (Panthera onca) in Pantanal, Brazil. Vector Borne Zoonotic Dis 2011; 11(8): 1001-1005. PMid:21612532. http://dx.doi.org/10.1089/vbz.2011.0619 